\title{
Penggunaan Teknologi Informasi dan Komunikasi dalam Pembelajaran oleh Guru Pendidikan Agama Islam
}

\author{
Idris Harun, Mohd. Fauzan
}

Universitas Islam Negeri Sultan Syarif Kasim Riau, Indonesia

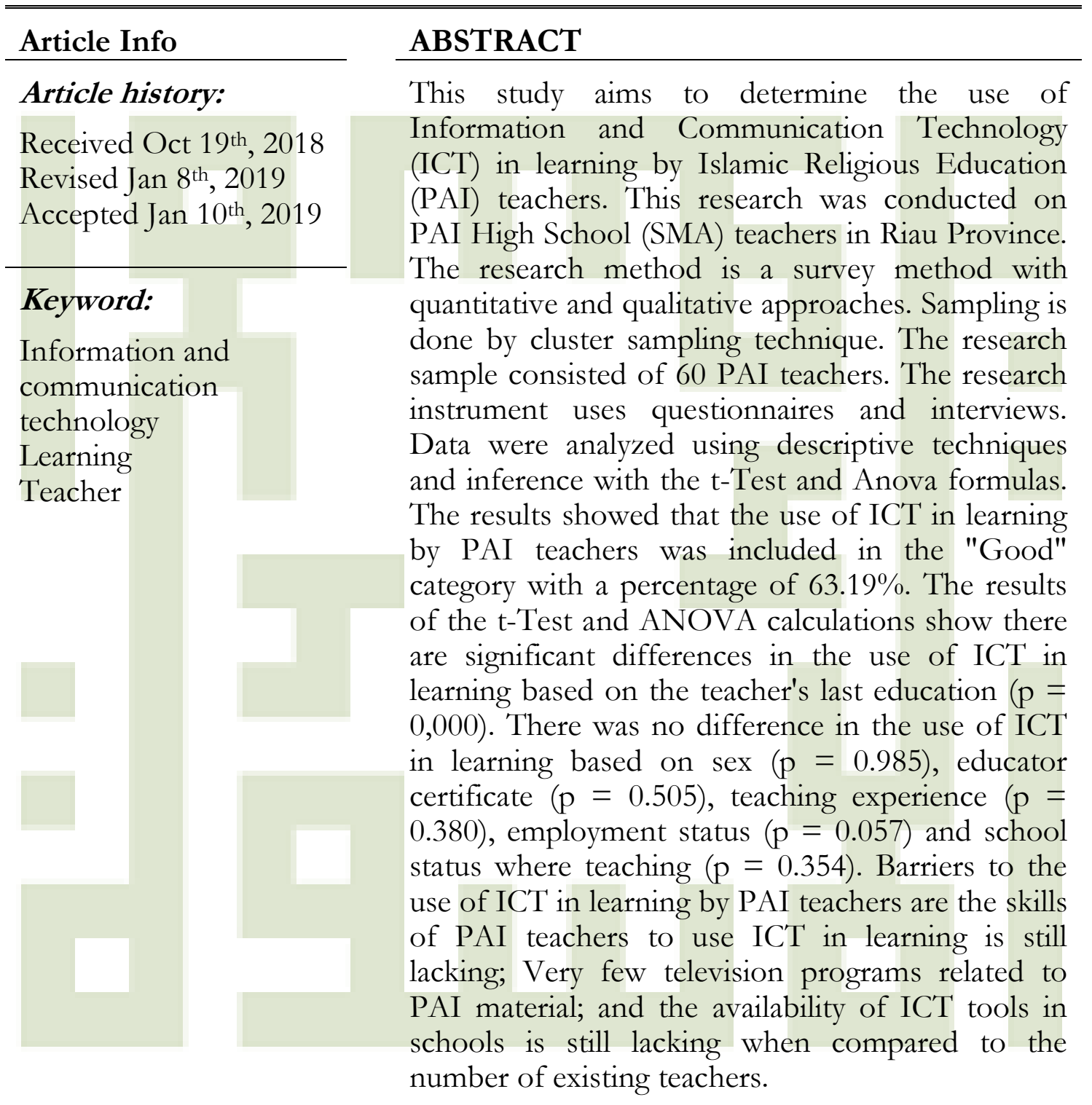

\section{Corresponding Author:}

\section{Idris Harun}

Universitas Islam Negeri Sultan Syarif Kasim Riau, Indonesia

Email: idrisharun@,uin-suska.ac.id 


\section{PENDAHULUAN}

Perkembangan teknologi informasi dan komunikasi (TIK) semakin pesat di era globalisasi saat ini. TIK telah membawa perubahan dalam berbagai aspek kehidupan manusia, termasuk dalam bidang pendidikan. Kemajuan TIK telah banyak membantu dan mempermudah aktifitas dalam pelaksanaan pendidikan, baik bagi para pendidik, peserta didik maupun penyelenggara pendidikan. Hal ini didukung dengan munculnya berbagai produk teknologi yang dapat digunakan sebagai media dan sumber pembelajaran. Penggunaan teknologi sebagai media dan sumber pembelajaran merupakan alternatif yang tepat untuk pengembangan pelaksanaan proses pembelajaran.

Beberapa hasil penelitian menunjukkan bahwa efektifitas pembelajaran dengan menggunakan teknologi lebih baik berbanding dengan pembelajaran tradisional atau konvensional. Hasil penelitian Rusman (2006) menunjukkan hasil belajar dengan menggunakan pembelajaran berbasis komputer model tutorial dan drill and practice jauh lebih baik dari pada pembelajaran konvensional. Wilfrid Laurier (1998) juga menghasilkan penelitian bahwa mahasiswa yang menggunakan web dalam pembelajaran terbukti dua kali lebih cepat waktu belajarnya dibanding mahasiswa klasikal, $80 \%$ mahasiswa tersebut berprestasi baik dan amat baik, serta $66 \%$ dari mereka tidak memerlukan bahan cetak. ${ }^{1}$

Pembelajaaran yang berkualitas mencerminkan adanya lingkungan belajar yang memberikan peluang kepada peserta didik untuk melakukan kontrol terhadap pemenuhan kebutuhan emosional-nya, melakukan pilihan-pilihan untuk ketelibatan mereka secara fisik dan mental dalam proses pembelajaran, serta lingkungan yang memberi mereka kebebasan untuk menentukan pilihan belajar sesuai dengan kemampuan, minat, dan bakat yang mereka miliki. Banyak faktor yang dapat mendukung terwujudnya proses pembelajaran yang berkualitas, salah satu di antaranya adalah penggunaan atau pemanfaatan TIK dalam pembelajaran.

Banyak kontribusi nyata yang dihasilkan oleh TIK bagi pendidikan, khususnya pembelajaran di sekolah. Media TIK dapat dimanfaatkan untuk meningkatkan kemampuan atau perbedaan individu peserta didik, mengajarkan konsep secara imajinatif dan kreatif dalam melaksanakan perhitungan, merangsang belajar peserta didik dan memberikan kesempatan untuk melakukan eksplorasi konsep secara mendalam. ${ }^{2}$

${ }^{1}$ Rusman, dkk, Pembelajaran Berbasis Teknologi Informasi dan Komunikasi (Jakarta: Rajawali Pers, 2012), 2

2Kemendikbud, Panduan Pembelajaran Elektronik (E-Learning) (Jakarta: Dirjendikdas, 2011), 3 
Kurikulum Pendidikan Agama Islam (PAI) di tingkat SMA juga telah menekankan pentingnya penggunaan TIK dalam proses pembelajaran. TIK diperlukan dalam mewujudkan kreativitas dan keterampilan peserta didik serta untuk mendapatkan informasi terbaru dalam rangka mencari gagasan untuk perancangan dan pembuatan bendabenda keterampilan sebagai wujud dari kreativitas peserta didik. ${ }^{3}$

Penggunaan TIK dalam pembelajaran sangat tergantung kepada kesediaan guru untuk menggunakannya dalam program pembelajaran serta kemampuan guru dalam menggunakan teknologi tersebut sebagai sumber dan media pembelajaran yang efektif. Oleh karena itu, setiap guru PAI harus senantiasa bersedia untuk menghadapi tantangan TIK yang semakin maju dan mereka juga harus mempunyai komitmen untuk menggunakan TIK dalam pembelajarannya. Berdasarkan permasalahan tersebut, maka perlu dilakukan penelitian untuk mengungkapkan penggunaan TIK dalam pembelajaran serta hambatan-hambatan yang dihadapi oleh guru PAI SMA di Provinsi Riau.

Tulisan ini bertujuan untuk mengetahui penggunaan TIK dalam pembelajaran oleh guru PAI SMA di Provinsi Riau dan hambatanhambatan yang mereka alami ketika menggunakan TIK dalam pembelajaran PAI.

3Depdiknas, Kurikulum 2004 Pendidikan Agama Islam Sekolah Menengah Atas dan Madrasab Aliyah (Jakarta: Balitbang Depdiknas, 2003), 15

\section{LANDASAN TEORI}

Teknologi informasi dan komunikasi (information and communication technology) terdiri dari dua konsep, yakni teknologi informasi dan teknologi komunikasi. Teknologi informasi adalah penggunaan peralatan elektronika, terutama komputer untuk menyimpan, menganalisis, dan mendistribusikan informasi apa saja, termasuk kata-kata, bilangan, dan gambar. Teknologi Informasi merupakan suatu teknologi yang digunakan untuk mengolah data, termasuk memproses, mendapatkan, menyusun, menyimpan, dan memanifulasi data berbagai cara untuk menghasilkan informasi yang berkualitas, yaitu informasi yang relevan, akurat, dan tepat waktu. ${ }^{4}$

Sedangkan teknologi komunikasi adalah perangkat-perangkat teknologi yang terdiri perangkat keras (hardware), perangkat lunak (software), proses, dan sistem yang digunakan untuk membantu proses komunikasi yang bertujuan agar komunikasi berhasil (komunikatif). ${ }^{5} \quad$ Teknologi komunikasi dapat digunakan untuk berkomunikasi antar individu atau kelompok orang yang tidak bertemu secara fisik di lokasi yang sama. Teknologi komunikasi dapat berupa telepon, radio, televisi, telex, fax, audio video, electronic data interchange, email, facebook, dan twiter.

Berdasarkan penjelasan di atas dapat disimpulkan bahwa teknologi informasi dan komunikasi adalah

4Rusman, dkk, Pembelajaran Berbasis..., 84 5Ibid., 85 
peralatan elektronika yang terdiri dari perangkat keras (hardware) dan perangkat lunak (software) serta segala kegiatan yang terkait dengan pemrosesan, manipulasi, pengelolaan, dan pemindahan informasi antarmedia.

Teknologi informasi dan komunikasi mencakup sistem-sistem komunikasi seperti komputer, televisi, video, dan internet. Semua model teknologi informasi dan komunikasi ini dapat digunakan sebagai alat atau media dalam menghasilkan informasi atau sejumlah data yang bermakna dan bermanfaat, terutama bagi penggunanya.

\subsection{Komputer}

Komputer adalah mesin penghitung elektronik yang cepat dan dapat menerima informasi input digital, kemudian memprosesnya sesuai dengan program yang tersimpan di memorinya dan menghasilkan output berupa informasi. ${ }^{6}$ Dapat disimpulkan bahwa komputer merupakan media elektronik yang dapat menerima informasi dalam bentuk input digital dengan menggunakan kode binner dalam aplikasi programnya, dan menampilkan output informasi dalam bentuk visualisasi data elektronik.

Komputer mempunyai beberapa manfaat untuk tujuan pendidikan, yaitu:

a. Komputer dapat mengakomodasi peserta didik yang lamban menerima pembelajaran

'Ibid., 46 karena ia dapat memberikan iklim yang lebih bersifat afektif dengan cara yang lebih individual, tidak pernah lupa, tidak pernah bosan, sangat sabar dalam menjalankan instruksi seperti yang diinginkan program yang digunakan.

b. Komputer dapat merangsang peserta didik untuk mengerjakan latihan, melakukan kegiatan laboratorium atau simulasi karena tersedianya animasi grafik, warna, dan music yang dapat menambah realism.

c. Kendali berada di tangan peserta didik, sehingga tingkat kecepatan belajar peserta didik dapat disesuaikan dengan tingkat penguasaanya. Artinya, komputer dapat berinteraksi dengan peserta didik seecara individual.

d. Kemampuan merekam aktivitas peserta didik selama menggunakan program pembelajaran, memberi kesempatan lebih baik untuk pembelajaran secara perorangan dan perkembangan setiap peserta didik selalu dapat dipantau.

e. Dapat berhubungan dengan, dan mengendalikan peralatan lain seperti CD interaktif, video, dan lain-lain dengan program pengendali dari komputer.

\subsection{Televisi}

Televisi adalah sistem elektronik yang mengirimkan gambar

7Ibid., 48 
diam dan gambar hidup bersama suara melalui kabel. Sistem ini menggunakan peralatan yang mengubah cahaya dan suara ke dalam gelombang elektrik dan mengkonversikannya kembali ke dalam cahaya yang dapat dilihat dan suara yang dapat didengar. ${ }^{8}$

Menurut Effendy, televisi adalah televisi siaran yang merupakan media dan jaringan komunikasi dengan ciri-ciri yang dimiliki komunikasi massa, yang berlangsung satu arah, komunikatornya melembaga, pesannya bersifat umum, sasarannya menimbulkan keserampakan, dan komunikasinya bersifat heterogen. ${ }^{9}$

Televisi juga merupakan panduan audio dari segi penyairannya dan video dari segi gambar bergeraknya. Apabila dihubungkan dengan pendidikan, televisi pendidikan adalah penggunaan program video yang direncanakan untuk mencapai tujuan pengajaran tertentu tanpa melihat siapa yang menyiarkan. Kelebihan media televisi terletak pada kekuatannya menguasai jarak dan ruang, sasaran yang dicapai untuk mencapai massa cukup besar, serta nilai aktualitas terhadap terhadap suatu liputan atau pemberitaan sangat cepat.

Menurut Effendy, televisi mempunyai tiga fungsi pokok, yaitu:

a. Fungsi penerangan (the information function). Televisi mendapat perhatian yang besar

8Ibid., 185

${ }^{9}$ Effendi, Televisi Siaran Teori dan Praktik. (Bandung: Mandar Maju, 1994), 21 di kalangan masyarakat karena dianggap sebagai media yang mampu menyiarkan informasi yang sangat memuaskan.

b. Fungsi pendidikan (the educational function). Televisi merupakan sarana yang ampuh untuk menyiarkan acara pendidikan kepada khalayak yang jumlahnya sangat banyak secara simultan dengan makna pendidikan, yaitu meningkatkan pengetahuan dan penalaran masyarakat. Dalam hal ini Pemerintah Indonesia melalui Kemendiknas dan Pustekom telah menyiarkan TV-edukasi (TVe), yang selalu menyiarkan program-program pendidikan dan pembelajaran seperti program siaran pe-ngayaan mata pelajaran untuk menghadapi Ujian Nasional (UN), mata kuliah di Universitas Terbuka (UT) dan Pendidikan Jarak Jauh (PJJ), dan program pendidikan lainnya.

c. Fungsi hiburan (The Entertainment function). Fungsi hiburan yang melekat pada televisi tampaknya lebih dominan dari pada fungsi lainnya. Fungsi hiburan ini amat penting karena ia menjadi salah satu kebutuhan manusia untuk mengisi waktu mereka dari aktivitas di luar rumah. ${ }^{10}$

\subsection{Video}

Video adalah serangkaian gambar gerak yang disertai suara

10Ibid. 
yang membentuk satu kesatuan yang dirangkai menjadi sebuah alur dengan pesan-pesan di dalamnya untuk ketercapaian tujuan pembelajaran yang disimpan dengan proses penyimpanan pada media pita atau disk. ${ }^{11}$ Media video pembelajaran dapat digolongkan ke dalam jenis media audio visual aids $(A V A)$ yaitu jenis media yang selain mengandung unsur suara juga mengandung unsur gambar yang bisa dilihat. Media video pembelajaran termasuk juga ke dalam media video cassette recorder (VCR) yaitu media audio visual bergerak yang perekamannya dilakukan dengan menggunakan kaset video dan penayangannya melalui pesawat televisi.

Ada beberapa format video, yaitu:

a. Pita video (video tape) adalah format media video yang terpaket dalam bentuk gulungan pita yang terbuka (open reel) atau yang tertutup dalam sebuah kaset.

b. Kaset video (video cassettes) adalah format media video yang terpaket dalam bentuk kaset yang berisi pita-pita video. Bentuk format kaset video ini dibedakan atas pita yang digunakan.

c. Piringan video (video disc) adalah jenis format media video yang memanfaatkan pancaran cahaya optik seperti tipe laser. Format video ini lebih mirip dengan jenis piringan hitam (gramophone), hanya saja berwarna keperakan atau berkilauan.

d. Compact disc (CD) adalah rekaman dengan cara menggunakan handycamp khusus yang dapat langsung merekam menggunakan CD. Untuk menampilkan gambar bergerak pada CD ikut ke dalam informasi verbal dan gambar diam yang dikontrol melalui program komputer.

e. High-Definition Television/HDTV adalah produksi video melaui HDTV yang menghasilkan jumlah bentuk gambar dan warna semakin akurat. Mutu gambar video ditentukan oleh banyaknya bentuk yang diproyeksikan ke atas permukaan tabung pada HDTV. Kualitas HDTV sudah sangat terbukti dari segi tampilannya yang istimewa. $^{12}$

\subsection{Internet}

Internet adalah jaringan komputer (interconnected network) di seluruh dunia yang berisikan informasi dan juga merupakan sarana komunikasi data atau suara, gambar, video dan teks. ${ }^{13}$ Informasi ini dibuat oleh pemilik jaringan komputer atau dibuat oleh pemilik informasi yang menitipkan informasinya kepada pemilik jaringan komputer. Internet juga sudah menjadi suatu

12Ibid., 219-220

13Nunu Mahnun, "Pemanfaatan Internet sebagai Sumber Belajar," Jurnal Potensia, Vol. 9, No. 1, (2010): 135 
pilihan dalam menyampaikan program-program pembelajaran. Sebagai salah satu hasil teknologi modern, internet merupakan salah satu cara yang mempunyai potensi paling kuat untuk pembelajaran dibandingkan teknologi lainnya karena dapat menyampaikan gambar bergerak, teks, suara dan dapat disimpan, informasi mudah dicari, serta pelaksanaan komunikasi dapat terjadi pada masa yang sama.

Para akademisi merupakan salah satu pihak yang paling diuntungkan dengan kemunculan internet. Berbagai bahan referensi, jurnal, buku, dan hasil penelitian yang dipublikasikan melalui internet tersedia dalam jumlah yang sangat banyak. Para guru dan peserta didik tidak lagi harus mengumpulkan buku-buku di perpustakaan sebagai bahan untuk proses pembelajaran, melainkan mereka cukup memanfaatkan search engine, sehingga materi-materi yang dibutuhkan dapat diperoleh dengan cepat. Selain menghemat tenaga dan biaya dalam proses pencariannya, materi-materi yang dapat ditemui di internet cenderung lebih terkini (up to date).

Internet juga dapat digunakan untuk pembelajaran secara on-line. Dalam pembelajaran on-line dapat digunakan kemudahan teknologi Website termasuk di dalamnya bypertext dan bypermedia, alat komunikasi tak bergerak (asynchronons) dan bergerak (synchronouns), peralatan audio dan video digital, protokol pemindahan fail, mesin pencari, alat pengembang
Web dan sistem manajemen pembelajaran. Pembelajaran on-line seperti sistem virtual dapat digunakan dalam melaksanakan pembelajaran jarak jauh. Sistem virtual ini telah mengubah konsep pembelajaran menjadi lebih menimbulkan rangsangan dan memberikan berbagai kemudahan. Peserta didik dapat masuk ke kelas virtual dengan mengakses internet dan membuka Website dari mata pelajaran yang ditawarkan. Seterusnya mereka dapat berkomunikasi dengan guru melalui mel elektronik untuk mendapatkan berbagai penjelasan tentang materi pembelajaran. ${ }^{14}$

Para peserta didik juga dapat menggunakan internet untuk belajar mandiri secara cepat sehingga akan meningkatkan dan memperluas pengetahuannya, belajar berinteraksi, dan mengembangkan kemampuan dalam bidang penelitian. Di samping itu, internet juga mempunyai beberapa manfaat bagi pendidikan di Indonesia yaitu, akses ke perpustakaan, akses ke pakar, perkuliahan online, layanan informasi akademik, menyediakan fasilitas mesin pencari data, menyediakan fasilitas diskusi, dan fasilitas kerjasama.

Dengan pertumbuhan teknologi informasi dan komunikasi yang pesat, internet telah menjadi suatu medium pembelajaran yang perlu dipertimbangkan kemanfaatannya. Menurut Koesnandar, internet

14Promadi, Pendekatan Komunikatif dalam Pembelajaran Bahasa Arab melahi Kelas Maya (Pekanbaru: Suska Press, 2008), 78 
mempunyai potensi yang besar dalam pembelajaran, baik sebagai sumber belajar, media, maupun pendukung pengelolaan proses pembelajaran. Mengingat berbagai ragam informasi tersedia di internet dan dapat diakses secara lebih mudah, kapan saja dan di mana saja, sehingga internet menjadi suatu kebutuhan dalam kehidupan sehari-hari. Selain itu, pengguna internet juga dapat berkomunikasi dengan berbagai pihak lain secara mudah melalui teknik e-moderating yang tersedia di internet. $^{15}$

Jaringan internet juga menyediakan beberapa aplikasi yang dapat digunakan oleh pemakai intenet yaitu e-mail/massaging, mailing list, file transfer protocol, ghoper, telnet, talk, chat, i-phone, world wide web (www), dan game online. Berbagai aplikasi ini perlu diketahui dan digunakan oleh guru dan peserta didik dalam hal positif atau sebagai sumber pembelajaran. Artinya, internet dapat memberikan informasi yang sifatnya mendidik, positif dan bermanfaat bagi manusia dalam proses pembelajaran.

Teknologi informasi seperti komputer, televisi, dan video merupakan sarana yang efektif digunakan dalam kegiatan pembelajaran. Penggunaan teknologi informasi untuk kegiatan pembelajaran sangat tidak terbatas. Banyak kontribusi nyata dihasilkan oleh teknologi informasi bagi

\footnotetext{
15Koesnandar, "Studi Pemanfaatan Edukasinet di Sekolah," www.eedukasi.net/artikel/index.php?id $=46$
}

pendidikan, khususnya pembelajaran di sekolah.

Penggunaan teknologi informasi untuk pembelajaran PAI dapat dikelompokkan menjadi tiga fungsi, ${ }^{16}$ yaitu:

a. Media pembelajaran mandiri. Media pembelajaran mandiri diantaranya yaitu pemutaran film dan CD interaktif. Pemutaran film dapat digunakan oleh guru dengan memilih jenis film yang ada seperti film yang bersifat given artinya suatu paket judul film yang telah tersedia dan relevan dengan pembelajaran Pendidikan Agama Islam. Selain itu, penggunaan CD interaktif dapat digunakan oleh guru agar peserta didik melakukan interaksi atau perlakuan terhadap program yang ditawarkan pada CD tersebut. Misalnya CD interaktif soaljawab tentang Pendidikan Agama Islam dikemas dalam bentuk permainan seperti dalam "Who Want to be Millionare." Dalam hal ini, guru Pendidikan Agama Islam atau pihak sekolah harus memiliki koleksi film atau CD interaktif yang berkaitan dengan materi Pendidikan Agama Islam sesuai dengan kurikulum yang digunakan.

b. Alat bantu pembelajaran. Teknologi informasi yang

16Idris, "Efektifitas Penggunaan TIK dalam Pembelajaran PAI," Jurnal Potensia, Vol. 14 Edisi 2 (2015): 187 
dimanfaatkan untuk alat bantu pembelajaran yaitu, pemanfaatan softwere komputer untuk pembelajaran Pendidikan Agama Islam. Di antara contoh software pendidikan yang dikenal yaitu, Computer Assisted Instruction (CAI), pada umumnya software ini sangat baik untuk keperluan remedial; Intelligent Computer Assited Learning (ICAL), dapat digunakan untuk materi atau konsep; Computer Assisted Training (CAT); Computer Assisted Design (CAD); dan Computer Assisted Media (CAM).

c. Sumber pembelajaran. Teknologi informasi yang terkait sebagai sumber pembelajaran (learning resources) dalam bentuk internet dengan segala komponennya. Materi yang ditampilkan dalam sebauh web yang terkait dengan Pendidikan Agama Islam dapat dilacak terlebih dahulu oleh guru dan dipraktekkan langsung oleh peserta didik. Maksud pelacakan oleh guru agar materi atau informasinya relevan dengan tujuan kurikuler Pendidikan Agama Islam.

\section{METODE PENELITIAN}

Penelitian ini menggunakan metode survei dengan pendekatan kuantitatif dan kualitatif. Populasi penelitian ini adalah guru mata pelajaran Pendidikan Agama Islam (PAI) SMA di Kota Pekanbaru, Kabupaten Kampar dan Kabupaten
Bengkalis. Pengambilan sampel menggunakan teknik cluster sampling yaitu pemilihan sampel didasarkan pada kelompok, daerah, atau kelompok subjek yang secara alami berkumpul bersama. Teknik kluster digunakan untuk penelitian lapangan yang wilayahnya luas. ${ }^{17}$ Sampel yang digunakan berjumlah 60 orang guru PAI dengan rincian masing-masing 20 orang di Kota Pekanbaru, Kabupaten Kampar dan Kabupaten Bengkalis.

Teknik pengumpulan data dalam penelitian ini adalah menggunakan angket dan wawancara. Angket diberikan kepada guru PAI untuk mengetahui tahap penggunaan TIK dalam pembelajaran. Angket yang digunakan mengacu pada model skala Likert dengan lima skala yaitu selalu, sering, kadang-kadang, jarang sekali, dan tidak pernah. Sedangkan wawancara dilakukan kepada guru PAI untuk mengetahui hambatanhambatan yang mereka alami ketika menggunakan TIK dalam pembelajaran.

Teknik analisis data yang digunakan dalam penelitian ini adalah analisis deskriptif dan inferensi. Data kuantitatif dari hasil angket akan dianalisis dengan menggunakan statistik deskriptif, t-Test dan Anova. Analisis ini menggunakan program Statistical Package for the Social of Sciences (SPSS) versi 22.0 for Windows. Standar deskriptif yang digunakan sebagai berikut:

${ }^{17}$ Sukardi, Metodologi Penelitian Pendidikan, (Jakarta: Bumi Aksara, 2005), hlm. 61 
a. $81-100 \%$ = Sangat Baik

b. $61-80 \%=$ Baik

c. $41-60 \%$ = Cukup Baik

d. $21-40 \%=$ Kurang Baik

e. $0-20 \%=$ Tidak Baik

Sedangkan data kualitatif dari

hasil wawancara akan dianalisis secara interaktif yang mengandung empat komponen yang saling berkaitan yaitu pengumpulan data, penyederhanaan data, pemaparan data, dan penarikan kesimpulan.

\section{HASIL PENELITIAN DAN PEMBAHASAN}

Hasil penelitian menggunakan statistik deskriptif untuk mengetahui tahap penggunaan TIK oleh guru PAI. Hasil analisis diperoleh nilai persentase penggunaan TIK dalam pembelajaran oleh guru PAI SMA di Provinsi Riau adalah 63,19\% atau Baik.

Hasil penelitian menggunakan statistik inferensi berupa t-Test dan Anova untuk mengetahui perbandingan penggunaan TIK dalam pembelajaran oleh guru PAI berdasarkan jenis kelamin, pendidikan terakhir, sertifikat pendidik, pengalaman mengajar, status pekerjaan, dan status sekolah tempat mengajar.

Penggunaan TIK berdasarkan jenis kelamin diperoleh nilai rata-rata guru laki-laki 53,73 dan guru perempuan 53,70. Berdasarkan hasil perhitungan t-test diperoleh nilai signifikan sebesar 0,985 . Nilai 0,985 $>0,05$. Berdasarkan perolehan data ini, maka $\mathrm{Ho}$ diterima dan $\mathrm{Ha}$ ditolak. Kesimpulannya bahwa tidak terdapat perbedaan signifikan penggunaan TIK dalam pembelajaran oleh guru PAI berdasarkan jenis kelamin.

Penggunaan TIK berdasarkan pendidikan terakhir diperoleh nilai rata-rata guru berpendidikan terakhir $\mathrm{S} 2=59,27$ dan $\mathrm{S} 1=51,33$ Berdasarkan hasil perhitungan t-test diperoleh nilai signifikan sebesar 0,000. Nilai $0,000<0,05$. Berdasarkan perolehan data ini, maka $\mathrm{Ha}$ diterima dan $\mathrm{Ho}$ ditolak. Kesimpulannya bahwa terdapat perbedaan signifikan penggunaan TIK dalam pembelajaran oleh guru PAI berdasarkan pendidikan terakhir.

Penggunaan TIK berdasarkan sertifikat pendidik diperoleh nilai rata-rata guru mempunyai sertifikat pendidik 54,06 dan guru belum mempunyai sertifikat pendidik 52,75. Berdasarkan hasil perhitungan t-test diperoleh nilai signifikan sebesar 0,505. Nilai $0,505>0,05$. Berdasarkan perolehan data ini, maka $\mathrm{Ho}$ diterima dan $\mathrm{Ha}$ ditolak. Kesimpulannya bahwa tidak terdapat perbedaan signifikan penggunaan TIK dalam pembelajaran oleh guru PAI berdasarkan sertifikat pendidik.

Penggunaan TIK berdasarkan pengalaman mengajar diperoleh nilai rata-rata guru berpengalaman mengajar 1-5 tahun 51,11, 6-10 tahun 54,85 dan lebih dari 10 tahun 53,70. Berdasarkan hasil perhitungan Anova diperoleh nilai signifikan sebesar 0,380. Nilai $0,380>0,05$. Berdasarkan perolehan data ini, maka 
Ho diterima dan $\mathrm{Ha}$ ditolak. Kesimpulannya bahwa tidak terdapat perbedaan signifikan penggunaan TIK dalam pembelajaran oleh guru PAI berdasarkan pengalaman mengajar.

Penggunaan TIK berdasarkan status pekerjaan dipoeroleh nilai ratarata guru PNS 55,48, guru kontrak 50,50 dan guru honorer 52,40. Berdasarkan hasil perhitungan Anova diperoleh nilai signifikan 0,057 . Nilai $0,057>0,05$. Berdasarkan perolehan data ini, maka Ho diterima dan $\mathrm{Ha}$ ditolak. Kesimpulannya bahwa tidak terdapat perbedaan signifikan penggunaan TIK dalam pembelajaran oleh guru PAI berdasarkan status pekerjaan.

Penggunaan TIK berdasarkan status sekolah diperoleh nilai ratarata guru mengajar di sekolah negeri 54,20 dan sekolah swasta 52,37. Berdasarkan hasil perhitungan t-test diperoleh nilai signifikan 0,354 . Nilai $0,354>0,05$. Berdasarkan perolehan data ini, maka Ho diterima dan $\mathrm{Ha}$ ditolak. Kesimpulannya tidak terdapat perbedaan signifikan penggunaan TIK dalam pembelajaran oleh guru PAI berdasarkan status sekolah.

Hasil analisis data wawancara kepada guru PAI tentang hambatanhambatan penggunaan TIK dalam pembelajaran dapat disimpulkan sebagai berikut:

a. Keterampilan guru PAI untuk menggunakan TIK dalam pembelajaran masih kurang. Guru perlu diberikan pelatihan khusus tentang pengunaan TIK sebagai sumber dan media pembelajaran, terutama teknologi internet.

b. Khusus televisi, acara yang ditayangkan oleh sebagian besar televisi masih banyak bersifat hiburan dan film. Sangat sedikit sekali acara televisi yang berkaitan dengan materi PAI.

c. Ketersediaan alat-alat TIK di sekolah masih kurang jika dibandingkan dengan guru yang ada. Akibatnya guru harus bergiliran jika ingin selalu menggunakan alat TIK dalam proses pembelajaran.

\section{KESIMPULAN}

Setelah melakukan penelitian tentang penggunaan teknologi informasi dan komunikasi (TIK) dalam pembelajaran oleh guru PAI SMA di Provinsi Riau, maka penulis menyimpulkan beberapa hasil penelitian sebagai berikut:

a. Penggunaan TIK dalam pembelajaran oleh guru PAI termasuk dalam kategori Baik dengan nilai persentase $63,19 \%$.

b. Hasil perhitungan t-Test dan Anova menunjukkan bahwa terdapat perbedaan signifikan penggunaan TIK dalam pembelajaran oleh guru PAI berdasarkan pendidikan terakhir guru. Guru berpendidikan S2 lebih sering menggunakan TIK daripada guru berpendidikan S1. Selanjutnya tidak terdapat perbedaan penggunaan TIK berdasarkan jenis kelamin, 
sertifikat pendidik, pengalaman mengajar, status pekerjaan dan status sekolah tempat mengajar.

c. Hambatan-hambatan penggunaan TIK dalam pembelajaran oleh guru PAI yaitu Keterampilan guru PAI untuk menggunakan TIK dalam pembelajaran masih kurang; Acara yang ditayangkan oleh sebagian besar televisi masih banyak bersifat hiburan dan film atau sangat sedikit sekali yang berkaitan dengan materi PAI; dan ketersediaan alat-alat TIK di sekolah masih kurang jika dibandingkan dengan guru yang ada.

\section{REFERENSI}

[1] Depdiknas. Kurikulum 2004 Pendidikan Agama Islam Sekolah Menengah Atas dan Madrasah Aliyah. Jakarta: Balitbang Depdiknas, 2003.

[2] Effendi. Televisi Siaran Teori dan Praktik. Bandung: Mandar Maju, 1994

[3] Idris, "Efektifitas Penggunaan TIK dalam Pembelajaran PAI." Jurnal Potensia, Vol. 14 Edisi 2 (2015)

[4] Kemendikbud. Panduan Pembelajaran Elektronik (ELearning). Jakarta: Dirjendikdas, 2011.

[5] Koesnandar. "Studi Pemanfaatan Edukasinet di Sekolah." 2007. www.eedukasi.net/artikel/index.php?i $\underline{\mathrm{d}=46}$
[6] Mahnun, Nunu. "Pemanfaatan Internet sebagai Sumber Belajar," Jurnal Potensia, Vol. 9, No. 1 (2010)

[7] Promadi, Pendekatan Komunikatif dalam Pembelajaran Babasa Arab melalui Kelas Maya. Pekanbaru: Suska Press, 2008

[8] Rusman, dkk. Pembelajaran Berbasis Teknologi Informasi dan Komunikasi. Jakarta: Rajawali Pers, 2012.

[9] Sukardi. Metodologi Penelitian Pendidikan Jakarta: Bumi Aksara, 2005.

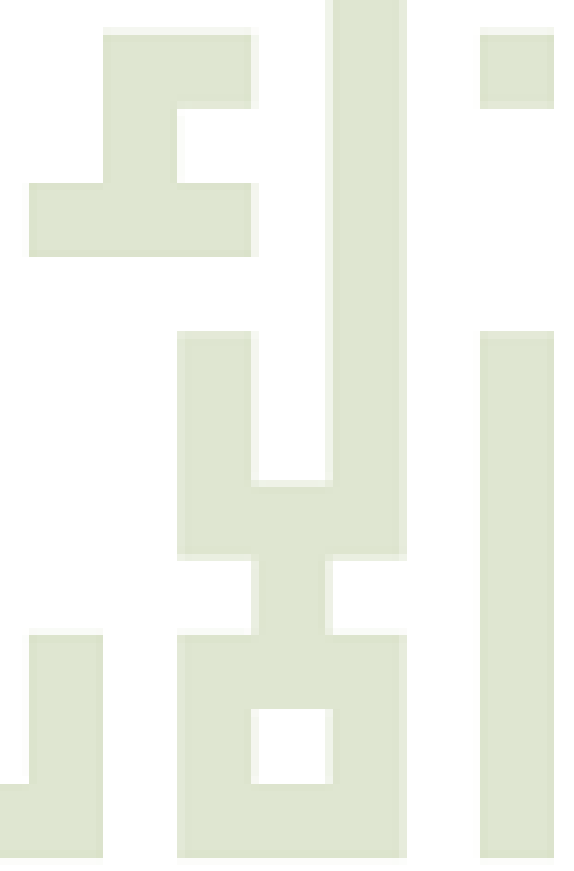

